\title{
Influences of environmental conditions in the fish assemblage structure of a tropical estuary
}

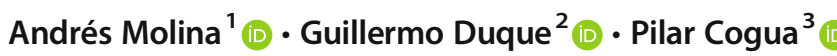

Received: 10 May 2018 / Revised: 28 September 2019 / Accepted: 19 December 2019 / Published online: 14 January 2020

(C) The Author(s) 2020

\begin{abstract}
Three fish assemblages (functional groups according to estuary use) were examined, which presented different responses to environmental variations, mainly associated to the dry and rainy seasons and high and low salinities and temperatures in the Buenaventura Bay estuary, Colombia, Tropical Eastern Pacific. In total, 4674 individuals were collected, belonging to 69 species of 29 families. The most abundant species was Sphoeroides trichocephalus (35\% of the total density). The assemblage of estuarine-resident fishes showed high tolerance to environmental variations since these were present all along the estuary and throughout the year. The assemblage of marine estuarine-dependent species was associated with the rainy season and low salinities and temperatures. The assemblages of marine estuarine opportunist fishes were associated with areas of higher environmental variability in both seasons, dry and rainy. Fish species belonging to the same functional group showed variations in their response to environmental changes which evidenced complex spatial and temporal dynamics. Understanding these changes is necessary to generate effective management plans based on scientific ecological knowledge, which include environmental impacts present in this estuary such as microplastics, heavy metals, and effects of dredging, and their effects on the ecosystem.
\end{abstract}

Keywords Estuarine fishes · Functional groups $\cdot$ Tropical Eastern Pacific $\cdot$ Buenaventura Bay

\section{Introduction}

The estuaries are characterized by their high geomorphological and environmental complexity, which is reflected in their high physicochemical variability (Elliott and Quintino 2007; Day et al. 2012), which is strongly related

Communicated by S. E. Lluch-Cota

Electronic supplementary material The online version of this article (https://doi.org/10.1007/s12526-019-01023-0) contains supplementary material, which is available to authorized users.

Andrés Molina

aemolinas@unal.edu.co

1 Instituto de Estudios en Ciencias del Mar-CECIMAR, Universidad Nacional de Colombia, Sede Caribe, INVEMAR, Calle 25 \# 2-55, Rodadero Sur, Playa Salguero, Santa Marta, Colombia

2 Facultad de Ingeniería y Administración (Ingeniería Ambiental), Universidad Nacional de Colombia, Sede Palmira, Carrera 32 Chapinero, vía Candelaria, Palmira, Colombia

3 Facultad de Ciencias Básicas, Universidad Santiago de Cali, Calle 5 \# 62-00 Barrio Pampalinda, Cali, Colombia to hydrological circulation patterns, mainly due to changes in the discharge of freshwater into the system (Wolanski et al. 2004, 2006; Sun et al. 2009). These environmental variations generate different responses from the community of estuarine organisms (Chícharo et al. 2009; Teichert et al. 2017), related to the characteristics of their life cycle, the possibility of taking advantage of shelter and food opportunities, and their physiological characteristics (Sheaves et al. 2013; Potter et al. 2015; Winemiller et al. 2015). This generates individual distribution patterns of organisms, which is evidenced by changes in density and biomass (Able 2005; Elliott et al. 2007; Sheaves et al. 2013).

The effect of the environmental variability on the structure of estuarine fish assemblages at different scales is well documented (Whitfield 1999), and in general, it is important to have a comprehensive understanding of the estuarine processes and their mechanisms at each particular estuary (Sheaves and Johnston 2009; França et al. 2011; Vilar et al. 2013; Teichert et al. 2017), which is somewhat addressed in this study. Estuaries are important not only for their importance as spawning areas, which influence the distribution of fish and invertebrates (Elliott et al. 2007; Martino and Houde 2010; 
Lima et al. 2015), but also for the high food availability (Nagelkerken et al. 2008; Lima et al. 2015; Ferreira et al. 2016). Other factors include the use of the estuary as nursery grounds (Sheaves et al. 2013) and shelter during different stages of their life cycle (Elliott et al. 2007; Sheaves et al. 2013; Potter et al. 2015), which lead to changes in species composition, density, and biomass along the estuary (Blaber et al. 1989; Sheaves et al. 2013; Ferreira et al. 2016). On the other hand, the supply of resources and competition (Blaber et al. 1989; Day et al. 2012; Le Pape and Bonhommeau 2015; Whitfield 2016; Teichert et al. 2017), along with tolerance or preference for specific environmental conditions (Blaber et al. 1989; Able 2005; Sheaves and Johnston 2009; Whitfield et al. 2012), also influence the use that fish have of estuaries, which is reflected in variations of the fish assemblage, spatially and temporally. All these processes and forms of use of estuaries are regulated by changes in the environmental conditions, mainly in the hydrological patterns (Wolanski et al. 2004, 2006; Sun et al. 2009). Nevertheless, due to the complexity of the estuarine ecosystems, the understanding of how fishes respond to environmental fluctuations is a work in progress (Elliott and Quintino 2007; França et al. 2012; Sheaves et al. 2016; Teichert et al. 2017).

Many studies have evaluated the importance of different environmental variables in assemblages of estuarine fishes at different spatial scales (Sheaves and Johnston 2009; Vilar et al. 2013; Pasquaud et al. 2015), concluding that variations in their specific environmental and morphological characteristics generate unique dynamics in the assemblages of fishes in each estuary, which must be understood within patterns at larger scales (Sheaves 2016). According to this, it is necessary to study the specific ecological dynamics of each estuary at different area scales and at different seasons. In the case of tropical estuaries, the study of these variations is important for the recognition of their high species richness throughout these scales (Pasquaud et al. 2015). Therefore, comprehensive knowledge of the dynamic ecosystem of the Buenaventura Bay estuary is necessary to adjust wildlife management and conservation policies (Blaber 2013; Sheaves 2017).

This study is aimed at contributing to the understanding of the response patterns of fish assemblages due to environmental changes in tropical estuaries, analyzing spatial and temporal distribution of species, density, and biomass. This knowledge will be useful for filling the gap in the poor knowledge of the estuarine fish assemblages of the Pacific coast of South America (Blaber 2013; Castellanos-Galindo et al. 2013), especially for the estuaries of the Colombian Pacific, and generating a baseline to evaluate and estimate the different impacts that take place in Buenaventura Bay estuary such as contamination by microplastics, heavy metals, and dredging effects (unpublished data).

\section{Materials and methods}

\section{Study area}

The Buenaventura Bay is an estuarine system located on the Pacific coast of Colombia ( $3^{\circ} 48^{\prime} 09.99^{\prime \prime}-3^{\circ} 52^{\prime} 38.57^{\prime \prime} \mathrm{N} ; 77^{\circ}$ 06' 30.75" $\left.-77^{\circ} 09^{\prime} 25.96^{\prime \prime} \mathrm{W}\right)$, Tropical Eastern Pacific (Fig. 1). Being located in the Intertropical Convergence Zone and the proximity to the Andes Mountain range, it is one of the most humid regions in the world (Cantera and Blanco 2001), with a mean air temperature of $25.9^{\circ} \mathrm{C}$, a relative humidity of $80-95 \%, 228-298$ days of rainfall per year, and average annual precipitation of $6508 \mathrm{~mm}$ (Lobo-Guerrero 1993). From January to June, the total monthly average precipitation is $200 \mathrm{mmto} 500 \mathrm{~mm}$, with low rain season (dry season), and from July to December, the total monthly average precipitation is $500 \mathrm{~mm}$ to $>700 \mathrm{~mm}$, with higher rain season (rainy season), having high precipitation $(755 \mathrm{~mm}$ ) for $2015 \mathrm{in}$ November and low precipitation (272 mm) in June (Fig. 2a). The mean depth is $5 \mathrm{~m}$ and has two tributary rivers, Anchicayá and Dagua $\left(427 \mathrm{~m}^{3} \mathrm{~s}^{-1}\right)$ which give it characteristics of a positive estuary (Gamboa-García et al. 2018). This estuary can be considered a well-mixed system, to present differences between the salinity of the bottom and the surface smaller than 2 (Otero 2005). Buenaventura Bay estuary was divided into four areas according to salinity gradient, geomorphology, and environmental characteristics (Fig. 1). In the inner part of the bay, area 1 (A1) is located in the south $\left(3^{\circ} 50^{\prime} 32.36^{\prime \prime}-3^{\circ} 50^{\prime}\right.$ $\left.56.29^{\prime \prime} \mathrm{N} ; 77^{\circ} 06^{\prime} 33.29^{\prime \prime}-77^{\circ} 07^{\prime} 09.50^{\prime \prime} \mathrm{W}\right)$, with direct influence from the rivers, and area 2 (A2) is located in the north ( $3^{\circ} 50^{\prime} 22.15^{\prime \prime}-3^{\circ} 52^{\prime} 00.51^{\prime \prime} \mathrm{N} ; 77^{\circ} 07^{\prime} 08.82^{\prime \prime}-77^{\circ} 09^{\prime} 14.00^{\prime \prime}$ $\mathrm{W})$, with less influence from rivers. In the part of the estuary with greater marine influence, area 3 (A3) is located to the south ( $3^{\circ} 48^{\prime} 50.69^{\prime \prime}-3^{\circ} 49^{\prime} 14.51^{\prime \prime} \mathrm{N} ; 77^{\circ} 08^{\prime} 46.41^{\prime \prime}-77^{\circ}$ $\left.09^{\prime} 24.74^{\prime \prime} \mathrm{W}\right)$, with influence from rivers, and area 4 (A4) to the north $\left(3^{\circ} 50^{\prime} 21.99^{\prime \prime}-3^{\circ} 50^{\prime} 46.35^{\prime \prime} \mathrm{N} ; 77^{\circ} 09^{\prime} 03.18^{\prime \prime}-\right.$ $77^{\circ} 09^{\prime} 35.92^{\prime \prime} \mathrm{W}$ ), with less influence from rivers. It is important to emphasize that this ecosystem has a high anthropic intervention since it has an estimated population for 2019 of 432,501 inhabitants (DANE 2005) and the most important port in Colombia (Diaz Merlano 2005).

\section{Sampling methods}

In this study, trawl samples were taken at four times of the year and in four areas of the estuary each time. Samples were taken at a depth (mean $\pm \mathrm{SE}$ ) of $2.1 \pm 0.6 \mathrm{~m}$. The field samplings along the year were carried out in April, June, September, and November of 2015. Nevertheless, the samples of April and June were analyzed together as the dry season and September and November as the rainy season. In each field trip, three trawl samples were taken in each of the four sampling areas (A1, A2, A3, and A4) (Fig. 1). Fish 


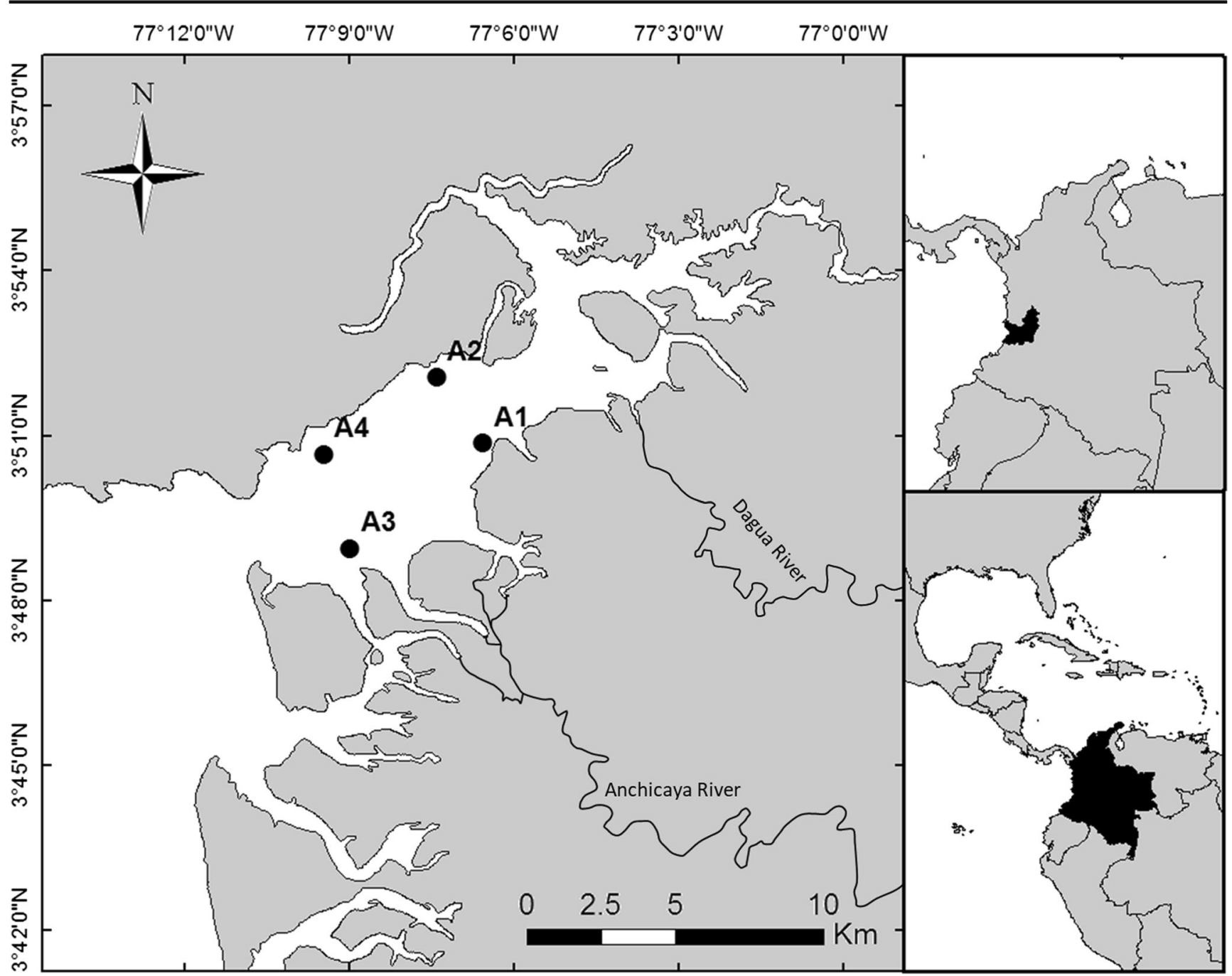

Fig. 1 Buenaventura Bay estuary indicating the sampling areas (A1, A2, A3, and A4)

samples were collected using artisanal otter trawl with 10min hauls each replicate. The net had a mesh size (between knots) of $25.4 \mathrm{~mm}$, ground rope of $3.6 \mathrm{~m}$, and head rope of $3.1 \mathrm{~m}$. The trawl speed was between 3.1 and $4.0 \mathrm{~km} \mathrm{~h}^{-1}$ and the swept area between 790 and $1011 \mathrm{~m}^{-2}$. The trawl area and catch per unit of effort used to estimate the density and biomass were calculated following the FAO proposal (Sparre and Venema 1997), assuming that the fraction of the head rope which was close to the width of the trawled area was $X_{2}=0.5$. Additionally, before each trawling, variables such as salinity, temperature $\left({ }^{\circ} \mathrm{C}\right)$, dissolved oxygen $\left(\mathrm{mg}^{-1}\right)$, and $\mathrm{pH}$ were measured in water at a depth of $50 \mathrm{~cm}$ (Thermo Scientific Orion Five Stars probe). These four variables have been found to be the ones that best correlate with variations in the structure of fish communities in estuaries around the world, representing seasonal hydrological changes and the influence of pollutants (Marshall and Elliott 1998; Whitfield 1999; Pombo et al. 2005; Rashed-Un-Nabi et al. 2011).

\section{Species classification}

The identification of fishes was determined by using the methods of Fischer et al. (1995a, b), Nelson (2006), Marceniuk et al. (2009, 2017), Robertson and Allen (2015), Froese and Pauly (2017), and Tavera et al. (2018). Total length $\left(L_{T}\right)$, standard length $\left(L_{\mathrm{S}}\right)$, and total weight $(\mathrm{g})$ were measured for all fishes. The fish species were classified into three estuarine use functional groups following Elliott et al. (2007) and Potter et al. (2015). The functional groups were (1) estuarine residents, species that develop all parts of their life cycle under estuarine conditions; (2) marine estuarine opportunistic, species that frequently enter the estuary in search of different resources, mainly food and shelter; and (3) marine estuarine dependent, species that depend on the estuary for the development of some part of their life cycle, mainly related to the reproduction and supply of food and shelter when they are juveniles. 
Fig. 2 Environmental variables. a Total monthly rainfall (gray bars) and historical pattern (1931-

2015) (black line) and mean \pm SE range of $\mathbf{b}$ salinity, $\mathbf{c}$ temperature, d dissolved oxygen, and $\mathbf{e} \mathrm{pH}$, in function of rainfall seasons and sampling areas. Rainfall < $500 \mathrm{~mm}$, dry season (diamond); rainfall $>500 \mathrm{~mm}$, rainy season (black dot). A1, area 1; A2, area $2 ; \mathrm{A} 3$, area $3 ; \mathrm{A} 4$, area 4
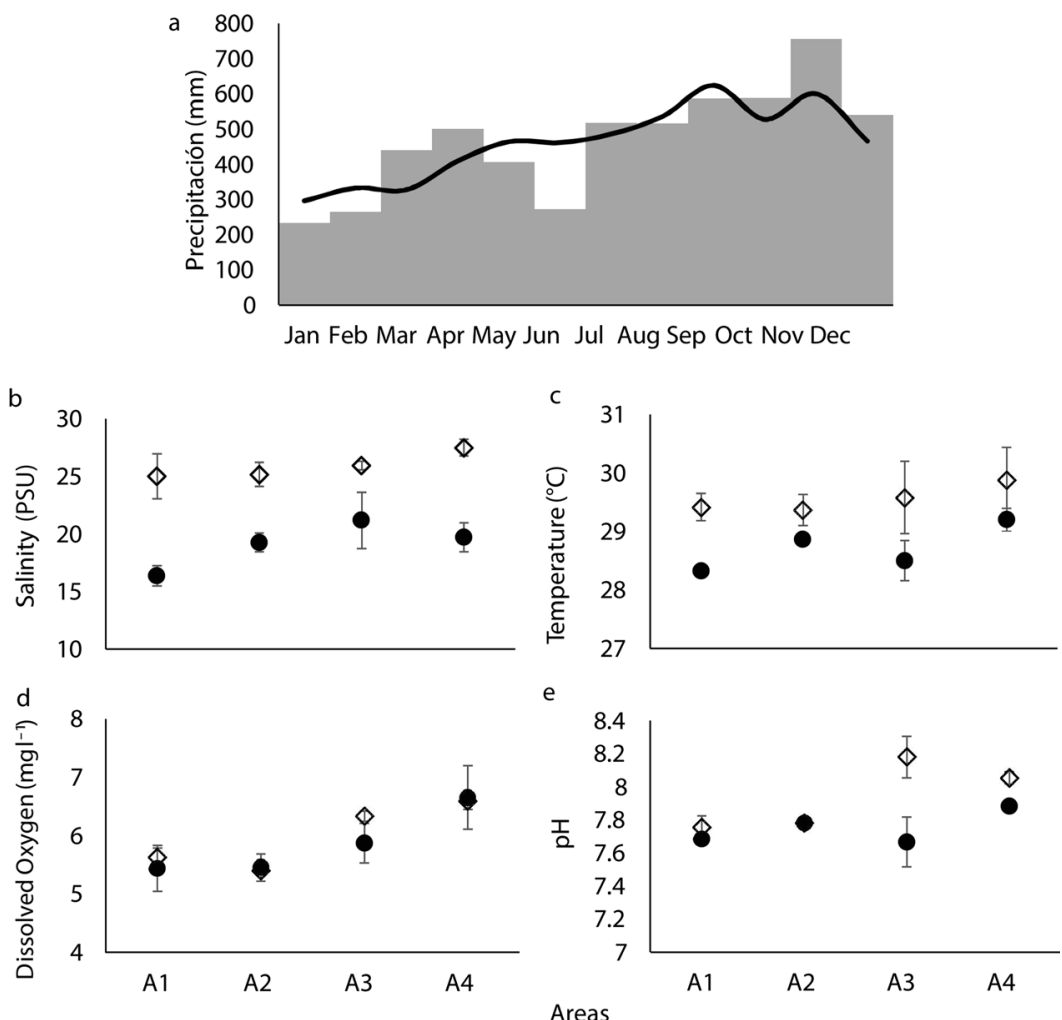

\section{Statistical analysis}

Differences in ecological descriptors of the fish community (number of species, density, and biomass) were assessed with two-way ANOVA ( $\alpha=0.05)$, with the season (dry and rainy) and sampling area (A1, A2, A3, and A4) as the main factors. To verify the homogeneity of variances, the Cochran test was used $(\alpha=0.05)$ and residual plots were examined to evaluate normality. The original data were transformed using the BoxCox method to improve normality (Box and Cox 1964). When significant differences were detected in ANOVA, the Bonferroni test ( $\alpha=0.05)$ was used to evaluate differences between pairs of groups (Quinn and Keough 2002). Since some fish species were seldom captured, 14 representative species were selected (Table 1), according to the species with higher values in the sum of the percentages of density, biomass, and frequency of occurrence. The density data were standardized, and a similarity matrix based on the BrayCurtis ranked index was constructed, with which the cluster analysis was done (Clarke 1993; Clarke et al. 2014). Pretreatment and cluster analysis was computed using PRIMER 7 (Clarke and Gorley 2015).

To detect ecological correlations and to evaluate the spatial and temporal variations of the fish assemblage structure, a canonical correspondence analysis (CCA) was conducted (Canoco 4.5) (ter Braak and Smilauer 2002). Moreover, a multiple regression analysis (least squares) was performed, with site scores from weighted averages of fish density as the dependent variable and environmental variables as the independent variables (ter Braak 1986; Palmer 1993; Legendre and Legendre 1998). The CCA was performed with transformed data (square root) and 1000 iterations (randomized areas) by the Monte Carlo test. These results were plotted to visualize the correlations between fish species and environmental variables as vectors (Leps and Smilauer 2003).

\section{Results}

\section{Environmental variables}

Spatial and temporal patterns were observed in the environmental variables showing seasonal variations in salinity, which was higher in the dry season, corresponding to January and June (mean $\pm \mathrm{SE}=25.9 \pm 0.6$ ), and lower in the rainy season, corresponding to July and December (19.1 \pm 0.8 ), including all study areas (Fig. 2). The lowest salinity $(16.4 \pm 0.9 \mathrm{PSU})$ was recorded in the area closest to the mouth of rivers (A1) in the rainy season and the highest salinity $(27.5 \pm 0.7 \mathrm{PSU})$ in the area of main marine influence (A4) in the dry season. The highest variability in salinity was recorded in the rainy season in A3 (coefficient of variation $(\mathrm{CV})$ $28.3 \%$ ) (Fig. 2b). The temperature showed little variation among seasons, being higher $\left(29.6 \pm 0.2^{\circ} \mathrm{C}\right)$ in the dry season 


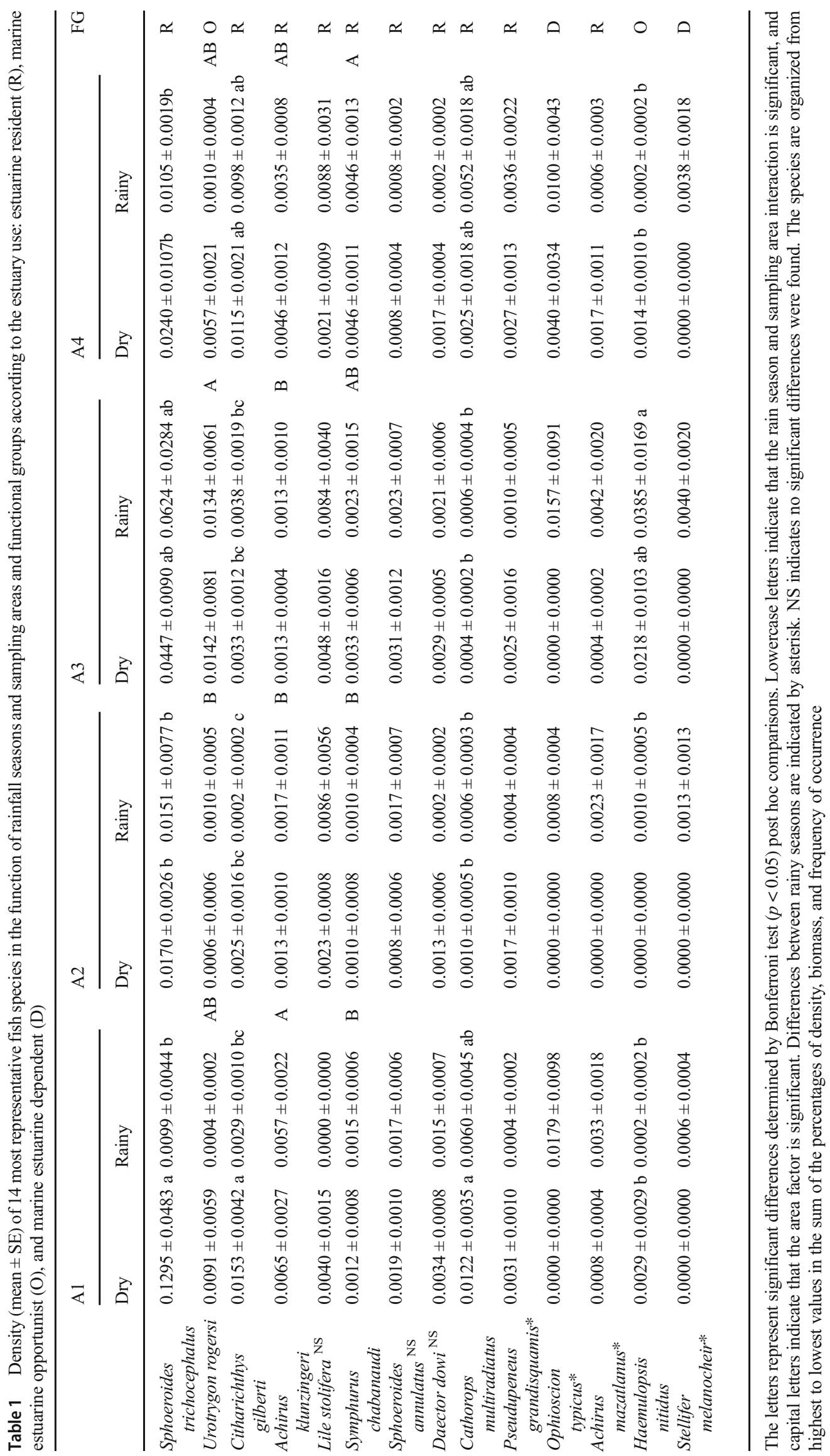


and lower $\left(28.7 \pm 0.1^{\circ} \mathrm{C}\right)$ in the rainy season. It was registered with the highest temperature in A4 in the dry season $(29.9 \pm$ $0.6^{\circ} \mathrm{C}$ ) and the lowest temperature in $\mathrm{A} 1$ in the rainy season $\left(28.3 \pm 0.1^{\circ} \mathrm{C}\right)$ (Fig. 2c). Concerning dissolved oxygen, a spatial pattern was observed, with the highest concentrations $\left(6.4 \pm 0.2 \mathrm{mg}^{-1}\right)$ in the areas of predominant marine influence (A3 and A4) and the lowest concentrations $\left(5.5 \pm 0.1 \mathrm{mg} \mathrm{l}^{-1}\right)$ in the internal areas (A1 and A2) (Fig. 2d). The pH values showed little variation in the internal areas in both dry (A1, $7.8 \pm 0.1 ; \mathrm{A} 2,7.8 \pm<0.1)$ and rainy $(\mathrm{A} 1,7.7 \pm<0.1 ; \mathrm{A} 2,7.8$ $\pm<0.1)$ seasons. Nevertheless, $\mathrm{pH}$ seasonal variations were observed in the external areas (A3 and A4), with the highest variability in A3 in the dry season with the highest value (8.2 $\pm 0.1)$, and the lowest value $(7.7 \pm 0.1)$ in the same area in the rainy season (Fig. 2e).

\section{Composition of the fish assemblages}

Total captures of fish varied between sampling areas and seasons. A total of 4674 individuals, weighing $132.16 \mathrm{~kg}$, belonging to 69 species of 29 families were collected, with an absolute mean density of $0.112 \pm$ 0.015 individuals $\mathrm{m}^{-2}$ and absolute mean biomass of $3.168 \pm 0.397 \mathrm{~g} \mathrm{~m}^{-2}$. The families with the highest number of species were Sciaenidae (12 species), Gerreidae, Haemulidae (both with 5 species), Ariidae, Carangidae, and Tetraodontidae (4 species each). In general, fish density was higher in the dry season $(59.5 \%)$, so was biomass $(55.2 \%)$ and the number of species $(91.3 \%)$ (Fig. 3). In the rainy season, there were fewer species $(77 \%)$. Spatially, in the dry season, the highest density, biomass, and number of species were recorded in A1 $(27.6 \%$, $22.9 \%$, and 43 species, respectively); the lowest density and biomass were observed in A2 $(6.9 \%$ and $5.2 \%$, respectively); and the lowest number of species in A3 (28 species). In the rainy season, the highest density and biomass were found in A3 (20.2\% and $20.9 \%$, respectively) and the highest number of species in A4 (34 species), while lower density, biomass, and number of species were observed in A2 (4.5\%, 3.8\%, and 25 species, respectively) (Fig. 3).

The species Sphoeroides trichocephalus, Haemulopsis nitidus, Citharichthys gilberti, Ophioscion typicus, Urotrygon rogersi, Lile stolifera, Cathorops multiradiatus, Achirus klunzingeri, Symphurus chabanaudi, Pseudupeneus grandisquamis, Daector dowi, Achirus mazatlanus, Sphoeroides annulatus, and Stellifer melanocheir comprised $90 \%$ of the total density and $81 \%$ of the total biomass. The dominant fish species in the Buenaventura Bay estuary were S. trichocephalus, with the highest density (35\% of the total density), and $U$. rogersi, with the highest biomass (23\% of total biomass).
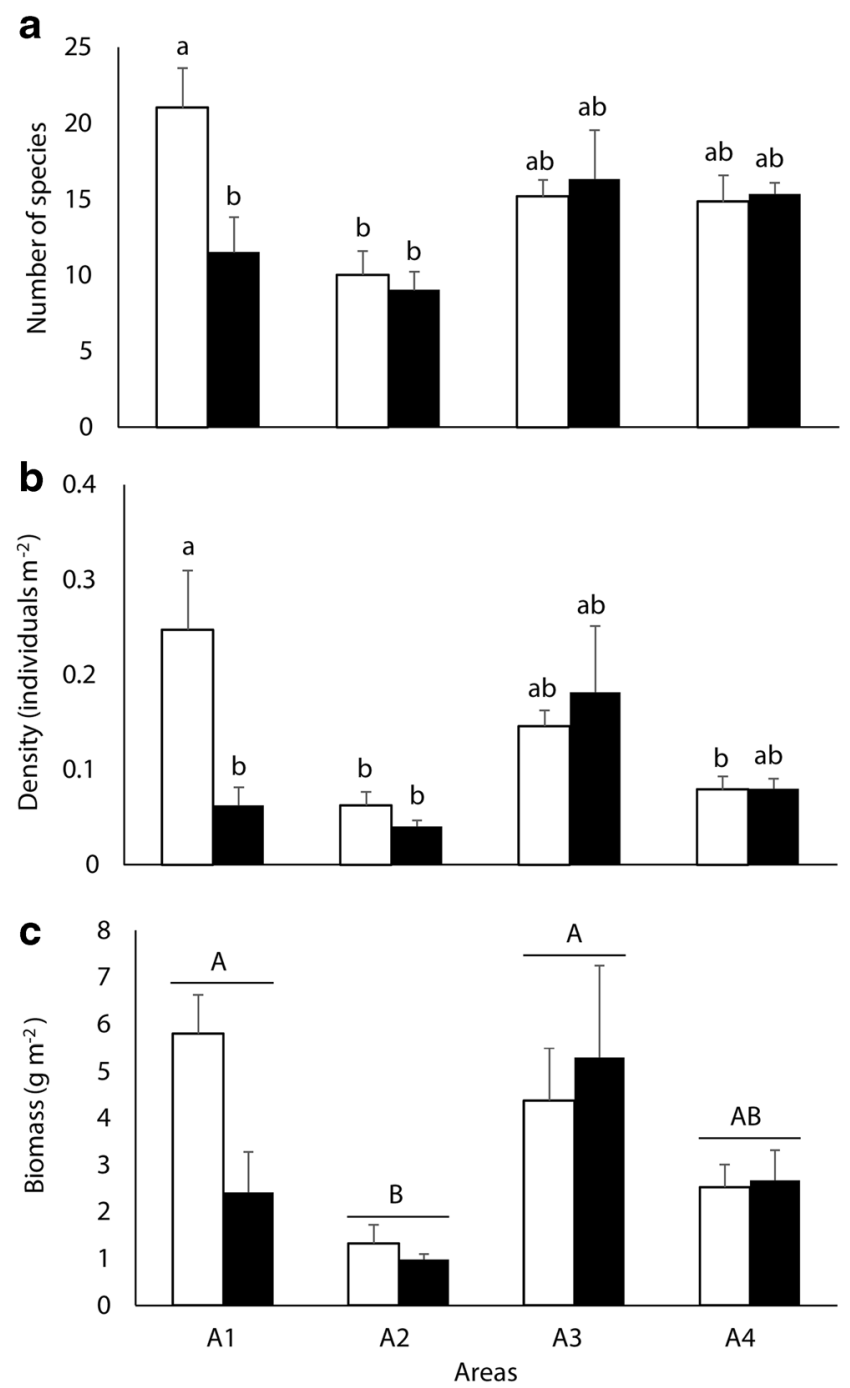

Fig. 3 Mean \pm SE range in the total number of species (a), density (b), and biomass (c) in function of rain seasons and sampling areas. Dry season (white bars), rainy season (black bars). A1, area 1; A2, area 2; $\mathrm{A} 3$, area 3 ; A4, area 4 . The letters represent significant differences determined by Bonferroni test $(p<0.05)$ post hoc comparisons. Lowercase letters indicate that the rain season and sampling area interaction is significant, and capital letters indicate that the area factor is significant

\section{Spatial and temporal variations}

The number of species varied significantly in the interaction among seasons and sampling areas $\left(F_{3,40}=3.142, p<0.05\right)$ and between areas $\left(F_{3,40}=5.048, p<0.01\right)$, but not among seasons. The main source of variance of the model was in A2 where the lowest number of species was recorded in both seasons and in A1 in the rainy season. In contrast, the highest number of species was recorded in A1 in the dry season (Fig. 3a).

Density also varied significantly in the interaction between rain seasons and sampling areas $\left(F_{3,40}=3.813, p<0.05\right)$ and between areas $\left(F_{3,40}=4.918, p<0.01\right)$, but not between rain seasons. The differences corresponded to the lower densities 
recorded in A2 and A4 in the dry and rainy seasons and in A1 in the rainy season, compared to the higher density recorded in A1 in the dry season (Fig. 3b).

The biomass presented only significant differences between areas $\left(F_{3,40}=5.830, p<0.01\right)$, being the main source of variation the lowest biomass recorded in $\mathrm{A} 2$ and the highest in $\mathrm{A} 1$ and $\mathrm{A} 3$, with the intermediate biomass recorded in A4 (Fig. 3c). Since the number of species, density, and biomass were influenced by one or both main effects (rain season and sampling area), fourteen representative species (high density, biomass, and frequency of occurrence) were selected and analyzed separately in all seasons and sampling areas (Table 1).

The mean density showed significant differences $(p<0.05)$ for the interaction of seasons and sampling areas for the species $S$. trichocephalus, $H$. nitidus, C. gilberti, and C. multiradiatus (Table 1). The species O. typicus, $P$. grandisquamis, A. mazatlanus, and S. melanocheir presented significant differences among seasons for density. Significant differences were also found between sampling areas for the density of species U. rogersi, A. klunzingeri, and $S$. chabanaudi. The species Lile stolifera, D. dowi, and $S$. annulatus did not present significant differences between seasons and sampling areas or for the interaction of these two factors. General, the main sources of variation were A1 in the dry season and A3 in the rainy season (Table 1).

\section{Patterns in the structure of fish assemblages and its relationship with environmental variables}

The fourteen species of fish selected were classified into two main groups, based on density data (cluster analysis; Fig. 4).
Group I consists of estuarine-resident species, common in both seasons, dry and rainy. This group was divided into two: the subgroup I-a, which presents high densities in A1 and A4 (C. multiradiatus, Pseudupeneus grandisquamis, Symphurus chabanaudi, A. klunzingeri, and C. gilbert), and the subgroup I-b, which presented high densities in A3 (L. stolifera, S. trichocephalus, Daector dowi, and Sphoeroides annulatus).

The second group (II) consisted of marine estuarine migratory species with higher densities either in one specific area or in only one season. This group was also divided into two groups: the subgroup II-a, formed by marine estuarine opportunistic species abundant in A3 (H. nitidus and U. rogersi), and the subgroup II-b, which consisted of marine estuarine dependent to the estuary species (O. typicus and Stellifer melanocheir) and Achirus mazatlanus, estuarine resident, which were recorded mainly during the rainy season.

The CCA shows the correlation between the density of the 14 most important fish species (high density, biomass, and frequency of occurrence) with the environmental variables in both sampling areas and seasons (Fig. 5). The first two axes explain $84.1 \%$ of the variance of the relationship between fish species and environmental conditions. The first axis showed a negative correlation with salinity $(p<0.05)$ and temperature, representing the gradient in the environmental conditions generated by seasons (Fig. 5, Table 2). The second axis is related to dissolved oxygen and $\mathrm{pH}$, representing differences between sampling areas.

The estuarine-resident fish species (S. trichocephalus, C. gilberti, L. stolifera, C. multiradiatus, A. klunzingeri, S. chabanaudi, P. grandisquamis, D. dowi, A. mazatlanus,
Fig. 4 Cluster dendrogram of representative species based on density similarity data between areas and seasons. The fish species were classified according to estuarine use functional groups: estuarine resident (triangle), marine estuarine opportunistic (black dot), and marine estuarine dependent (diamond)

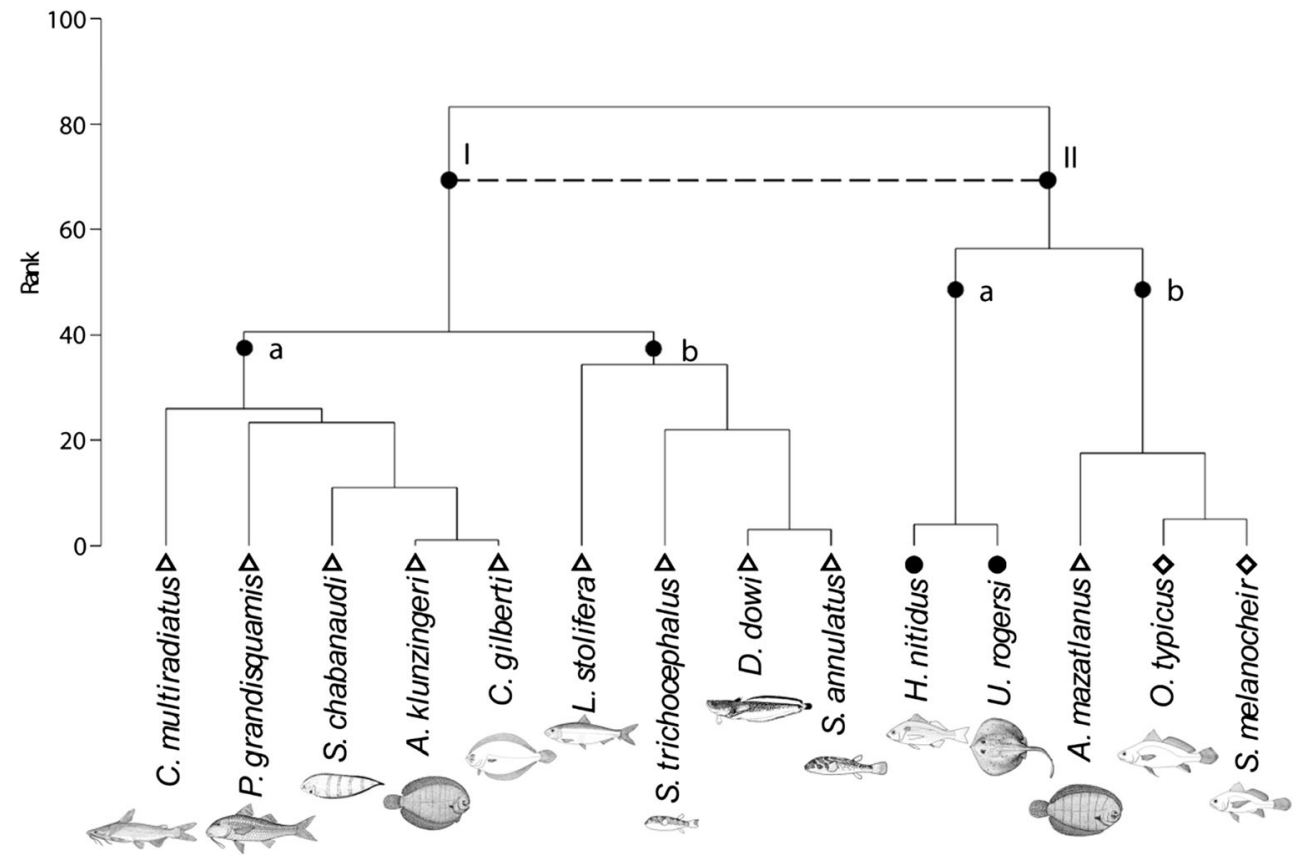




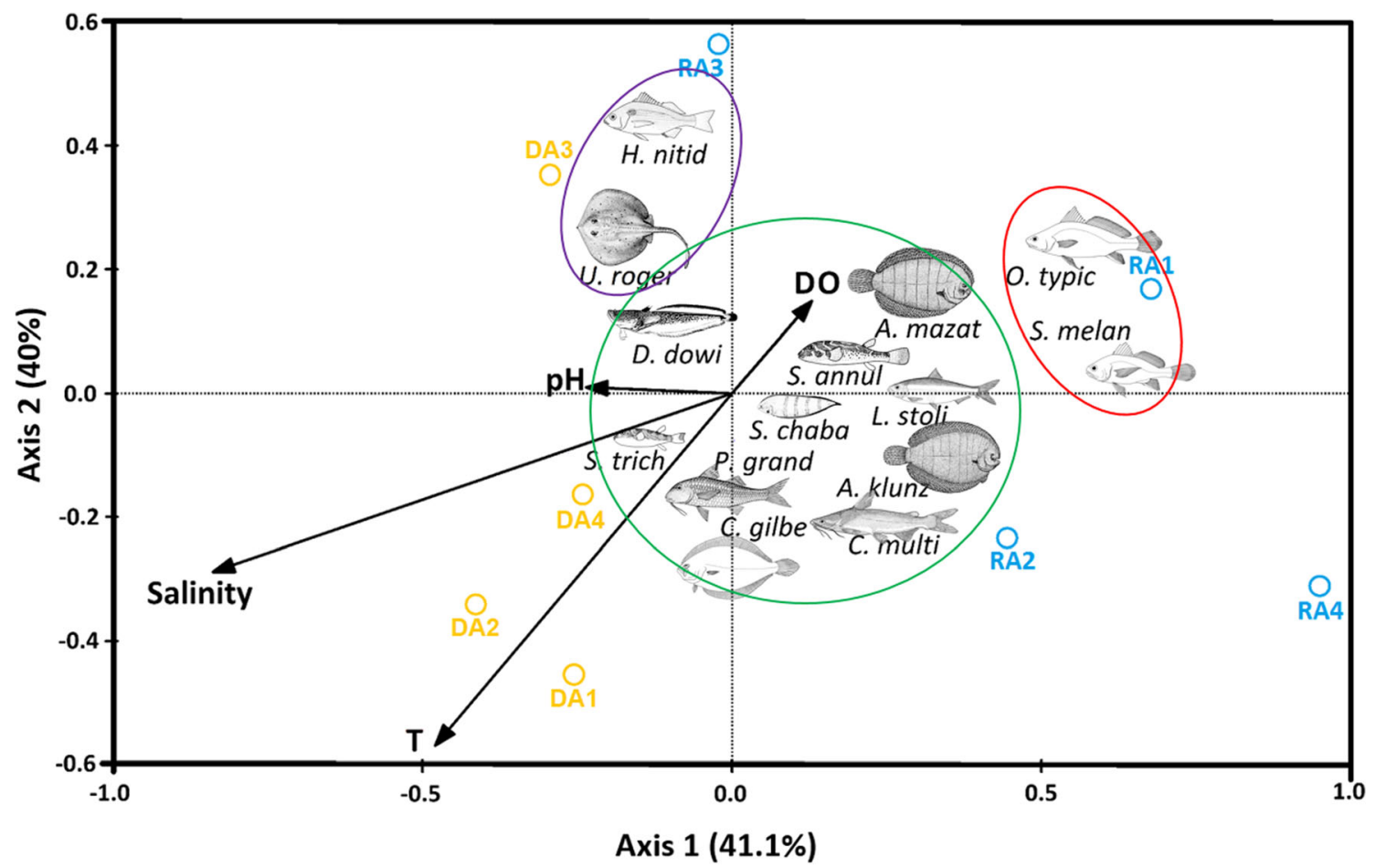

Fig. 5 CCA triplot for correlations between environmental variables and density of 14 most representative fish species. Arrows represent environmental variables: salinity, dissolved oxygen (DO), temperature $(T)$, and $\mathrm{pH}$. Unfilled circles represent the combination between rain seasons (D dry season, R rainy season) and study areas (A1, A2, A3, and A4). Filled circles represent the fish species (S. trich: S. trichocephalus, C. gilbe: C. gilberti, L. stoli: L. stolifera, C. multi:

and $S$. annulatus) form an assemblage within the estuary (represented by a group around the origin of the axes), with a high frequency in all sampling areas, in both seasons (Fig. 5). The marine estuarine-dependent species, $O$. typicus and S. melanocheir, form another assemblage, which was associated with low salinities and temperatures and to the rainy season (Fig. 5). The marine estuarine opportunistic species, H. nitidus and U. rogersi, form the last assemblage and were related to high concentrations of dissolved oxygen in A3 (Fig. 5).

\section{Discussion}

\section{Fish assemblages}

Patterns of variation between dry and rainy seasons and sampling areas were observed for the fish assemblage of Buenaventura Bay estuary.

The fish assemblage was dominated by 14 species $(20 \%)$ of the total of 69 species recorded. These 14 species represented $90 \%$ of the total fish density, which is to be expected for estuaries, where few species are the most
C. multiradiatus, A. klunz: A. klunzingeri, S. chaba: S. chabanaudi, P. grand: P. grandisquamis, D. dowi: D. dowi, A. mazat: A. mazatlanus, $\mathrm{S}$. annul: S. annulatus, O. typic: O. typicus, S. melan: S. melanocheir, H. nitid: $H$. nitidus, and U. roger: $U$. rogersi). Green circle, estuarine residents; purple circle, marine estuarine opportunistic; and red circle, marine estuarine dependent

dominant. This is usually due to the strong environmental variations, the wide range of resources, and the different ontological uses that fish make of the estuaries (Whitfield 1999). This few species dominance is similar to an estuary in Ecuador, where seven species (23\% of fish species) represented $95 \%$ of the total fish density (Shervette et al. 2007). Moreover, for an estuary in Costa Rica, the fish dominance reported was only for ten species (12\% of fish species), which represented the $63 \%$ of total fish density (Feutry et al. 2010), and in north of Brazil, where three species (4\% of fish species) represent more than $40 \%$ of the total biomass (Vilar et al. 2013).

In this study, the most abundant species was S. trichocephalus (Tetraodontidae) (Table 1), possibly because it is well adapted to the estuarine conditions (Nelson 2006) and its affinity for turbid waters and soft bottoms (Robertson and Allen 2015), environmental conditions characteristic of Buenaventura Bay estuary. In previous studies carried out in Buenaventura, the family Tetraodontidae, specifically S. annulatus, is reported as one of the most abundant species, with L. stolifera (Clupeidae) being the most abundant species (Rubio 1984a). In contrast, in the present study, L. stolifera was the sixth species in density ranking (4.3\%) and 
Table 2 Summary of CCA using density of 14 most important fish species and environmental variables. The environmental variables most correlated with each axis are indicated in italics.

\begin{tabular}{llll}
\hline Summary of CCA & Axis 1 & Axis 2 & $P$ value \\
\hline Eigenvalue & 0.186 & 0.169 \\
Species-environment correlation & 0.925 & 0.985 \\
Cumulative \% variance & & & \\
$\quad$ Of species data & 32.6 & 62.3 & \\
Of species-environment variables & 44.1 & 84.1 & \\
Correlation with environmental variables & & & 0.034 \\
Salinity & -0.862098 & -0.0213882 & 0.068 \\
Temperature & -0.666445 & -0.207559 & 0.482 \\
Dissolved oxygen & 0.0207171 & 0.275433 & 0.108 \\
pH & -0.439325 & 0.267755 & \\
\hline
\end{tabular}

S. annulatus the sixteenth (1.5\%), suggesting possible changes in the structure of the fish community in Buenaventura Bay estuary. Species of the family Tetraodontidae have been reported as one of the most abundant species in the CotoColorado estuary in Costa Rica (Feutry et al. 2010). In Malaga Bay, Colombian Pacific, an estuary near to Buenaventura Bay, L. stolifera, Centropomus armatus, Lutjanus argentiventris, Diapterus peruvianus, and Ariopsis simonsi are reported as dominant species (CastellanosGalindo et al. 2013), which are different to the dominant species found in Buenaventura Bay in this study. This variation among adjacent estuaries may be due to the much greater amount of sediments that are deposited by rivers into the Buenaventura bay estuary (Rubio 1984a, b). The most abundant species in other tropical estuaries of Central and South America are Cathorops fuerthii and A. mazatlanus, in Nayarit, Mexican Pacific (Amezcua et al. 1987); Anchoa hepsetus and Eucinostomus gula in Margarita Island, Venezuela (Ramírez Villaroel 1994); Cathorops agassizii and Stellifer naso in the north of Brazil; and Bagre marinus and Achirus lineatus in the northeast of Brazil (Vilar et al. 2013).

Significant differences were observed for species richness and total densities among seasons and areas, whereas differences in total biomass were found only among areas in Buenaventura Bay. These differences may be due to the diverse ontogenetic uses of the estuaries, not only as spawning, feeding, and growing areas but also for the wide environmental changes among seasons and areas such as salinity and suspended solids (Amezcua et al. 1987; Shervette et al. 2007; Feutry et al. 2010; Vilar et al. 2013). Additionally, the change in the supply of resources in estuaries due to natural (Nagelkerken et al. 2008; Lima et al. 2015) or anthropogenic (Amorim et al. 2017) causes might be also influencing the differences along the Buenaventura Bay estuary. Since significant spatial and temporal differences of fish richness, density, and biomass were found in this study, the most representative fish species were assessed separately.

\section{Movement of fish species in the estuary}

Among the representative species of fish evaluated individually, it was found that most of the species (six species) are estuarine residents ( $S$. trichocephalus, C. gilberti, L. stolifera, C. multiradiatus, A. klunzingeri, and $S$. chabanaudi) and are found along the estuary throughout the year (except for L. stolifera which was not recorded in A1 in the rainy season). Nevertheless, there were differences in these species densities and biomass, which may indicate that the use of the estuary by fish of similar functional groups is rather complex. This complexity has been reported also for ichthyoplankton in estuaries of the Western Indo-Pacific (Blaber et al. 1997) and northeastern Brazil (Lima et al. 2015) among others.

In the dry season, Sphoeroides trichocephalus was the most abundant for the area most influenced by rivers, whereas in the rainy season, it was abundant in an area with more marine influence and variability. This suggested that this species has a wide physiological tolerance to variations in salinity and higher levels of turbidity than other species (Robertson and Allen 2015). Moreover, this characteristic may be an advantage to avoid predation and to use the available resources associated with the suspended material supplied by rivers. In contrast, in a South Western Atlantic estuary (Guanabara Bay, Brazil), it was found that Tetraodontidae is moving into the estuary, seeking stable conditions that are associated to waters of high transparency and areas with greater marine influence (De Andrade et al. 2015). Lile stolifera did not present significant differences between areas and rain seasons, being a species well adapted to the estuarine conditions, for which it is the dominant species in several estuaries of Tropical Eastern Pacific (Castellanos-Galindo et al. 2013). The absence of L. stolifera in the inner zone of the estuary with a greater influence of the rivers in the rainy season probably responds to a preference for more stable conditions, despite being well adapted and common in estuaries (Castellanos-Galindo et al. 2013). Symphurus chabanaudi showed higher density and 
biomass in the areas with greater marine influence, which agrees with what was reported for the Gulf of Mexico, where they have registered a preference for deep waters (Rábagoquiroz et al. 2008). It was observed that $C$. gilberti, C. multiradiatus, and A. klunzingeri presented preference for the inner zone of the estuary with greater influence of the rivers in the dry season, and in the rainy season, they are distributed throughout the estuary, with the highest abundances in contrasting areas, the inner zone of the estuary with great influence of the rivers and the external zone of the estuary with less influence of the rivers. This distribution of abundance can be caused by the search for more stable conditions in response to the high environmental variability resulting from hydrological changes (Vilar et al. 2013). The permanence in the inner zone of the estuary with a greater influence of the rivers may be due to a strategy used to avoid competition and predation or by the availability of resources (Teichert et al. 2017), possibly related to the rivers discharge.

The marine estuarine opportunistic, H. nitidus and $U$. rogersi, presented the highest densities in the external zone of the estuary with great influence of the rivers and lowest in the other zones, which indicates a preference for more variable environmental conditions that generate supply of resources (Elliott et al. 2007; Potter et al. 2015). As a marine estuarine dependent, it was observed that $O$. typicus makes use of the estuary in a specific period of the year (the rainy season), which may be associated with a part of their life cycle. This behavior has been also reported for other species of the Sciaenidae family (Ferreira et al. 2016), and it has been observed in tropical estuaries in Australia for marine estuarinedependent species (Sheaves et al. 2013), possibly due to the use of the estuary as nursery by the Sciaenidae family (Phillips 1983), mainly during the rainy season (Sarpedonti et al. 2013).

\section{Influence of environmental conditions in fish assemblages}

In the Buenaventura Bay estuary, the most important fish species are distributed in three assemblages, according to their response to environmental variables and the characteristics of the functional group in which they were classified. The dry and rainy seasons were determinant in the structure of the fish assemblages. The most influential environmental variables were salinity and temperature.

The estuarine-resident assemblage consists of 10 species, which are S. trichocephalus, C. gilberti, L. stolifera, C. multiradiatus, A. klunzingeri, S. chabanaudi, P. grandisquamis, D. dowi, A. mazatlanus, and $S$. annulatus. These species showed greater tolerance to changes in environmental variables since they were found along the estuary and in both seasons. This pattern usually is found in species that are not dependent on changes in salinity (Sheaves and Johnston 2009; França et al. 2012).
The fish species that are estuarine resident, in general, have the largest number of species, which is common in tropical estuaries (Whitfield et al. 2012). These are especially true for the estuarine-resident species in Buenaventura Bay estuary since they were the most abundant and showed a high tolerance to wide changes in salinity.

The marine estuarine-dependent fish assemblage group was formed by $O$. typicus and $S$. melanocheir and was only registered in the rainy season, distributed along the estuary. This assemblage was associated with low salinities and temperatures. The relationship between salinity and fish species distribution in estuaries has been reported by several authors (Blaber et al. 1989; Sosa-López et al. 2007), mainly for nonresident estuarine species (Whitfield et al. 2012). On the other hand, the temperature has also been reported as one of the most influential environmental variables in the estuarine fish assemblages (Harrison and Whitfield 2006), with its relation to tolerance to changes in salinity being reported (Whitfield et al. 2012). The distribution along the estuary of these species, in the rainy season, might be related to hydrological changes that influence the freshwater input, which is the most influential factor in the distribution of the fish and the structure of the assemblages (Sosa-López et al. 2007; França et al. 2011; Pichler et al. 2015).

The marine estuarine opportunistic assemblage included $H$. nitidus and $U$. rogersi that were mainly present in the external zone of the estuary with great influence of the rivers in both dry and rainy seasons, possibly because of the high supply of resources associated with this area. This location is influenced by the discharge of the rivers and the marine conditions at the same time (Cantera and Blanco 2001), which generates a favorable condition for these opportunistic fish species (Whitfield 1999). It is known that the variation in the physicochemical properties of water affects the olfactory and vision capacity of fish, increasing some ecological interactions and possible increases in primary productivity due to the input of organic matter from rivers (Whitfield 1999). Moreover, high abundances of crustaceans have also been recorded in this area, which may be used as a food source (GamboaGarcía et al. 2018). In conclusion, all of the above may explain the presence of these species in large numbers throughout the year in this area.

In this study, the fish assemblage varied spatially and temporally, being influenced mainly by the difference between seasons, the salinity, and the temperature. It was also noted that fish make use of estuary areas with different environmental conditions throughout the year, identifying general dynamics for each functional group and specific for each species, which indicates that species of the same functional group may respond differently to environmental variations. This study shows that the Buenaventura Bay estuary has a high complexity and ecological importance, in spite of the high degree of anthropogenic intervention in this area. 
Acknowledgments The authors thank the Departamento Administrativo de Ciencia, Tecnología e Innovación de Colombia (COLCIENCIAS), for the doctoral fellowship awarded to Andrés Molina (Convocatoria $617 \mathrm{de}$ 2013), the research group on Ecology and Aquatic Pollution (ECONACUA) (for the name in Spanish) for their support in the collection and processing of samples, and Arturo Acero for his contributions in the identification of the fish.

Funding information This research was financed by the Universidad Nacional de Colombia, Sede Palmira (grant numbers 20101001813 and 20101001557), and the Universidad Santiago de Cali (grant number 934621116-D70).

\section{Compliance with ethical standards}

Conflict of interest The authors declare that they have no conflict of interest.

Ethical approval The methods used were approved by the ethics committee of the Institute of Environmental Studies of the Universidad Nacional de Colombia, following international, national, and institutional guidelines for the care and use of animals.

Sampling and field studies It is important to note that the fish collection was made with the authorization of the Ministry of Environment and Sustainable Development of Colombia (Resolution 0255 of March 12, 2014, issued by the National Authority of Environmental Licenses).

Data availability The datasets generated during and/or analyzed during the current study are available from the corresponding author on reasonable request.

Author Contribution AM and GD conceived and designed research. $\mathrm{AM}$ and GD conducted the field work. AM, and PC coordinated the lab work. AM, GD, and PC analyzed data. AM wrote the manuscript. All authors read and approved the manuscript.

Open Access This article is licensed under a Creative Commons Attribution 4.0 International License, which permits use, sharing, adaptation, distribution and reproduction in any medium or format, as long as you give appropriate credit to the original author(s) and the source, provide a link to the Creative Commons licence, and indicate if changes were made. The images or other third party material in this article are included in the article's Creative Commons licence, unless indicated otherwise in a credit line to the material. If material is not included in the article's Creative Commons licence and your intended use is not permitted by statutory regulation or exceeds the permitted use, you will need to obtain permission directly from the copyright holder. To view a copy of this licence, visit http://creativecommons.org/licenses/by/4.0/.

\section{References}

Able KW (2005) A re-examination of fish estuarine dependence: evidence for connectivity between estuarine and ocean habitats. Estuar Coast Shelf Sci 64:5-17. https://doi.org/10.1016/j.ecss. 2005.02.002

Amezcua F, Alvarez RM, Yañez-Arancibia A (1987) Dinámica y estructura de la comunidad de peces en un ecosistema ecológico de los manglares de la costa del Pacífico mexicano, Nayarit. An del Inst Ciencias del Mar y Limnoloía 14:221-248
Amorim E, Ramos S, Elliott M et al (2017) Habitat loss and gain: influence on habitat attractiveness for estuarine fish communities. Estuar Coast Shelf Sci 197:244-257. https://doi.org/10.1016/j.ecss.2017. 08.043

Blaber SJM (2013) Fishes and fisheries in tropical estuaries: the last 10 years. Estuar Coast Shelf Sci 135:57-65. https://doi.org/10.1016/j. ecss.2012.11.002

Blaber SJM, Brewer DT, Salini JP (1989) Species composition and biomasses of fishes in different habitats of a Tropical Northern Australian estuary: their occurrence in the adjoining sea and estuarine dependence. Estuar Coast Shelf Sci 29:509-531

Blaber SJM, Farmer MJ, Milton DA et al (1997) The ichthyoplankton of selected estuaries in Sarawak and Sabah: composition, distribution and habitat affinities. Estuar Coast Shelf Sci 45:197-208. https://doi. org/10.1006/ecss. 1996.0174

Box GE, Cox DR (1964) An analysis of transformations. J R Stat Soc Ser B 26:211-252

Cantera JR, Blanco JF (2001) The estuary ecosystem of Buenaventura Bay, Colombia. In: Seeliger U, Kjerfve B (eds) Coastal marine ecosystems of Latin America. Springer, Berlin, pp 265-280

Castellanos-Galindo GA, Krumme U, Rubio EA, Saint-Paul U (2013) Spatial variability of mangrove fish assemblage composition in the Tropical Eastern Pacific Ocean. Rev Fish Biol Fish 23:69-86. https://doi.org/10.1007/s11160-012-9276-4

Chícharo L, Ben Hamadou R, Amaral A et al (2009) Application and demonstration of the Ecohydrology approach for the sustainable functioning of the Guadiana estuary (South Portugal). Ecohydrol Hydrobiol 9:55-71. https://doi.org/10.2478/v10104-009-0039-3

Clarke KR (1993) Non-parametric multivariate analyses of changes in community structure. Aust Ecol 18:117-143. https://doi.org/10. 1111/j.1442-9993.1993.tb00438.x

Clarke KR, Gorley RN (2015) PRIMER v7: user manual/tutorial. PRIMER-E, Plymouth

Clarke KR, Gorley RN, Somerfield PJ, Warwick RM (2014) Change in marine communities: an approach to statistical analysis and interpretation, 3rd edn. PRIMER-E, Plymouth

DANE (2005) Proyecciones de población. In: Dep. Adm. Nac. Estadística - DANE. https://www.dane.gov.co/index.php/ estadisticas-por-tema/demografia-y-poblacion/proyecciones-depoblacion. Accessed 29 May 2019

Day JW, Crump BC, Kemp WM, Yáñez-Arancibia A (2012) Estuarine ecology. Estuar Ecol. https://doi.org/10.1002/9781118412787

De Andrade AC, Santos SR, Verani JR, Vianna M (2015) Guild composition and habitat use by Tetraodontiformes (Teleostei, Acanthopterygii) in a south-western Atlantic tropical estuary. J Mar Biol Assoc UK:1-14. https://doi.org/10.1017/ S0025315415001368

Diaz Merlano JM (2005) Deltas y Estuarios de Colombia. Imprelibros S.A., Samtiago de Cali

Elliott M, Quintino V (2007) The estuarine quality paradox, environmental homeostasis and the difficulty of detecting anthropogenic stress in naturally stressed areas. Mar Pollut Bull 54:640-645. https://doi. org/10.1016/j.marpolbul.2007.02.003

Elliott M, Whitfield AK, Potter IK et al (2007) The guild apprach to categorizing estuarine fish assemblages: a global review. Fish Fish 8:241-268. https://doi.org/10.1111/j.1467-2679.2007.00253.x

Ferreira GVB, Barletta M, Lima ARA et al (2016) Plastic debris contamination in the life cycle of Acoupa weakfish (Cynoscion acoupa) in a tropical estuary. ICES J Mar Sci J du Cons 73:2695-2707. https:// doi.org/10.1093/icesjms/fsw108

Feutry P, Hartmann HJ, Casabonnet H, Umaña G (2010) Preliminary analysis of the fish species of the Pacific Central American Mangrove of Zancudo, Golfo Dulce, Costa Rica. Wetl Ecol Manag 18:637-650. https://doi.org/10.1007/s11273-010-9183-1

Fischer W, Krupp F, Schneider W et al (1995a) Guía FAO para la identificación de especies para los fines de la pesca. 
Pacífico Centro - Oriental, II. Organización de las Naciones Unidas para la agricultura y la alimentación, Roma, FAO

Fischer W, F Krupp, Schneider W et al (1995b) Guía FAO para la identificación de especies para los fines de la pesca Pacifico Centro - Oriental, III. Organización de las Naciones Unidas para la agricultura y la alimentación, Roma, FAO

França S, Costa MJ, Cabral HN (2011) Inter- and intra-estuarine fish assemblage variability patterns along the Portuguese coast. Estuar Coast Shelf Sci 91:262-271. https://doi.org/10.1016/j.ecss.2010.10. 035

França S, Vasconcelos RP, Fonseca VF et al (2012) Predicting fish community properties within estuaries: influence of habitat type and other environmental features. Estuar Coast Shelf Sci 107:22-31. https://doi.org/10.1016/j.ecss.2012.04.013

Froese R, Pauly D (2017) Fishbase. In: World Wide Web Electron

Gamboa-García DE, Duque G, Cogua P (2018) Structural and compositional dynamics of macroinvertebrates and their relation to environmental variables in Buenaventura Bay. Bol Investig Mar y Costeras 47:67-83. https://doi.org/10.25268/bimc.invemar.2018.47.1.738

Harrison TD, Whitfield AK (2006) Estuarine typology and the structuring of fish communities in South Africa. Environ Biol Fish 75:269-293. https://doi.org/10.1007/s10641-006-0028-y

Le Pape O, Bonhommeau S (2015) The food limitation hypothesis for juvenile marine fish. Fish Fish 16:373-398. https://doi.org/10.1111/ faf. 12063

Legendre P, Legendre L (1998) Numerical ecology, 2nd edn. Elsevier B.V., Amsterdam

Leps J, Smilauer P (2003) Multivariate analysis of ecological data using CANOCO. Cambridge University Press, Cambridge

Lima ARA, Barletta M, Costa MF (2015) Seasonal distribution and interactions between plankton and microplastics in a tropical estuary. Estuar Coast Shelf Sci 165:213-225. https://doi.org/10.1016/j.ecss. 2015.05.018

Lobo-Guerrero AL (1993) Hidrología e Hidrogeología de la región Pacífica colombiana. In: Leyva P (ed) Colombia-Pacífico, Tomo I. Banco de la Republica, Santafé de Bogotá, pp 122-134

Marceniuk AP, Betancur-R R, Acero A (2009) A new species of Cathorops (Siluriformes); of four species from the Eastern Pacific. Bull Mar Sci 85:245-280

Marceniuk AP, Acero A, Cooke R, Betancur-R R (2017) Taxonomic revision of the New World genus Ariopsis Gill (Siluriformes: Ariidae), with description of two new species. Zootaxa 4290:1-42. https://doi.org/10.11646/zootaxa.4290.1.1

Marshall S, Elliott M (1998) Environmental influences on the fish assemblage of the Humber estuary, UK. Estuar Coast Shelf Sci 46:175184

Martino EJ, Houde ED (2010) Recruitment of striped bass in Chesapeake Bay: spatial and temporal environmental variability and availability of zooplankton prey. Mar Ecol Prog Ser 409:213-228. https://doi. org/10.3354/meps08586

Nagelkerken I, Blaber SJM, Bouillon S et al (2008) The habitat function of mangroves for terrestrial and marine fauna: a review. Aquat Bot 89:155-185. https://doi.org/10.1016/j.aquabot.2007.12.007

Nelson JS (2006) Fishes of tne world, 4th edn. Wiley, New Jersey

Otero LJ (2005) Aplicación de un modelo hidrodinámico bidimensional para describir las corrientes y la propagación de la onda de marea en la bahía de Buenaventura. Boletín Científico CCCP:9-21. https:// doi.org/10.26640/01213423.12.9

Palmer MW (1993) Putting things in even better order: the advantages of canonical correspondence analysis. Ecology 74:2215-2230

Pasquaud S, Vasconcelos RP, França S et al (2015) Worldwide patterns of fish biodiversity in estuaries: effect of global vs. local factors. Estuar Coast Shelf Sci 154:122-128. https://doi.org/10.1016/j.ecss.2014. 12.050
Phillips PC (1983) Observations on abundance and spawning seasons of three fish families from an El Salvador coastal lagoon. Rev Biol Trop 31:29-36

Pichler HA, Spach HL, Gray CA et al (2015) Environmental influences on resident and transient fishes across shallow estuarine beaches and tidal flats in a Brazilian World Heritage area. Estuar Coast Shelf Sci 164:482-492. https://doi.org/10.1016/j.ecss.2015.07.041

Pombo L, Elliott M, Rebelo JE (2005) Environmental influences on fish assemblage distribution of an estuarine coastal lagoon, Ria de Aveiro (Portugal). Sci Mar 69:143-159. https://doi.org/10.3989/ scimar.2005.69n1143

Potter IC, Tweedley JR, Elliott M, Whitfield AK (2015) The ways in which fish use estuaries: a refinement and expansion of the guild approach. Fish Fish 16:230-239. https://doi.org/10.1111/faf.12050

Quinn GP, Keough MJ (2002) Experimental design and data analysis for biologists. Cambridge University Press, Cambridge

Rábago-quiroz CH, López-martínez J, Herrera-valdivia E, Nevárezmartínez MO (2008) Population dynamics and spatial distribution of flatfish species in shrimp trawl bycatch in the Gulf of California. Hidrobiologica 18:177-188

Ramírez Villaroel P (1994) Estructura de la Comunidad de Peces de la Laguna de Raya, Isla de Margarita, Venezuela. Ciencias Mar 20:116

Rashed-Un-Nabi M, Abdulla MAM, Hadayet MU, Mustafa MG (2011) Temporal and spatial distribution of fish and shrimp assemblage in the bakkhali river estuary of Bangladesh in relation to some water quality parameters. Mar Biol Res 7:436-452. https://doi.org/10. 1080/17451000.2010.527988

Robertson DR, Allen GR (2015) Shorefishes of the Tropical Eastern Pacific: online information system. In: Smithson. Trop. Res. Institute, Balboa, Panamá. http://biogeodb.stri.si.edu/sftep/en

Rubio EA (1984a) Estudios sobre la ictiofauna del Pacífico colombiano I. Composición taxonómica de la ictiofauna asociada al ecosistema manglar estuario de la bahía de Buenaventura. Cespedesia 13:296315

Rubio EA (1984b) Estudio Taxonómico Preliminar de la Ictiofauna de bahía Málaga (Pacífico Colombiano). Boletín Investig Mar y costeras 14:157-173

Sarpedonti V, da Anunciação ÉMS, Bordalo AO (2013) Spatio-temporal distribution of fish larvae in relation to ontogeny and water quality in the oligohaline zone of a north Brazilian estuary. Biota Neotrop 13: 55-63. https://doi.org/10.1590/S1676-06032013000300007

Sheaves M (2016) Simple processes drive unpredictable differences in estuarine fish assemblages: baselines for understanding site-specific ecological and anthropogenic impacts. Estuar Coast Shelf Sci 170: 61-69. https://doi.org/10.1016/j.ecss.2015.12.025

Sheaves M (2017) How many fish use mangroves? The 75\% rule an illdefined and poorly validated concept. Fish Fish 18:778-789. https:// doi.org/10.1111/faf.12213

Sheaves M, Johnston R (2009) Ecological drivers of spatial variability among fish fauna of 21 tropical Australian estuaries. Mar Ecol Prog Ser 385:245-260. https://doi.org/10.3354/meps08040

Sheaves M, Johnston R, Johnson A et al (2013) Nursery function drives temporal patterns in fish assemblage structure in four tropical estuaries. Estuar Coasts 36:893-905. https://doi.org/10.1007/s12237013-9610-7

Sheaves M, Baker R, Abrantes KG, Connolly RM (2016) Fish biomass in tropical estuaries: substantial variation in food web structure, sources of nutrition and ecosystem-supporting processes. Estuar Coasts 40:580-593. https://doi.org/10.1007/s12237-016-0159-0

Shervette VR, Aguirre WE, Blacio E et al (2007) Fish communities of a disturbed mangrove wetland and an adjacent tidal river in Palmar, Ecuador. Estuar Coast Shelf Sci 72:115-128. https://doi.org/10. 1016/j.ecss.2006.10.010

Sosa-López A, Mouillot D, Ramos-Miranda J et al (2007) Fish species richness decreases with salinity in tropical coastal lagoons. J 
Biogeogr 34:52-61. https://doi.org/10.1111/j.1365-2699.2006. 01588.x

Sparre P, Venema SC (1997) Introducción a la evaluación de recursos pesqueros tropicales. Parte 1: manual. FAO, Roma

Sun T, Yang ZF, Shen ZY, Zhao R (2009) Environmental flows for the Yangtze estuary based on salinity objectives. Commun Nonlinear Sci Numer Simul 14:959-971. https://doi.org/10.1016/j.cnsns. 2007.10.006

Tavera J, Acero PA, Wainwright PC (2018) Multilocus phylogeny, divergence times, and a major role for the benthic-to-pelagic axis in the diversification of grunts (Haemulidae). Mol Phylogenet Evol 121: 212-223. https://doi.org/10.1016/j.ympev.2017.12.032

Teichert N, Pasquaud S, Borja A et al (2017) Living under stressful conditions: fish life history strategies across environmental gradients in estuaries. Estuar Coast Shelf Sci 188:18-26. https://doi.org/10. 1016/j.ecss.2017.02.006

ter Braak CJF (1986) Canonical correspondence analysis: a new eigenvector technique for multivariate direct gradient analysis. Ecology 67:1167-1179. https://doi.org/10.1111/j.1600-0706.2010.18376.x

ter Braak CJF, Smilauer P (2002) CANOCO reference manual and CanoDraw for Windows user's guide: software for canonical community ordination (version 4.5). www.canoco.com, NY

Vilar CC, Joyeux JC, Giarrizzo T et al (2013) Local and regional ecological drivers of fish assemblages in Brazilian estuaries. Mar Ecol Prog Ser 485:181-197. https://doi.org/10.3354/meps10343
Whitfield AK (1999) Ichthyofaunal assemblages in estuaries: a South African case study. Rev Fish Biol Fishs 9:151-186

Whitfield AK (2016) Biomass and productivity of fishes in estuaries: a South African case study. J Fish Biol 89:1917-1930. https://doi.org/ $10.1111 / \mathrm{jfb} .13110$

Whitfield AK, Elliott M, Basset A et al (2012) Paradigms in estuarine ecology - a review of the Remane diagram with a suggested revised model for estuaries. Estuar Coast Shelf Sci 97:78-90. https://doi. org/10.1016/j.ecss.2011.11.026

Winemiller KO, Fitzgerald DB, Bower LM, Pianka ER (2015) Functional traits, convergent evolution, and periodic tables of niches. Ecol Lett 18:737-751. https://doi.org/10.1111/ele.12462

Wolanski E, Boorman LA, Chicharo L et al (2004) Ecohydrology as a new tool for sustainable management of estuaries and coastal waters. Wetl Ecol Manag 12:235-276. https://doi.org/10.1007/s11273-005$4752-4$

Wolanski E, Chicharo L, Chicharo MA, Morais P (2006) An ecohydrology model of the Guadiana estuary (South Portugal). Estuar Coast Shelf Sci 70:132-143. https://doi.org/10.1016/j.ecss. 2006.05.029

Publisher's note Springer Nature remains neutral with regard to jurisdictional claims in published maps and institutional affiliations. 